\title{
Religious values in global communication of modern society: trends in the development and transformation
}

\author{
Ekaterina Bobyreva $^{1, *}$, Marina Zheltukhina $^{1}$, Kristina Korovina $^{1}$, and Maryana Busygina ${ }^{1}$ \\ ${ }^{1}$ Volgograd State Socio-Pedagogical University, 27, Lenin av., 400066, Volgograd, Russia
}

\begin{abstract}
The article is devoted to the investigation of religious values development and transformation at the modern stage of society's development. The functioning of values is the influence of the latter on human activity, human behavior, on social life and on the development of culture. Religious values are the most fundamental part of any culture and society and don't change quickly. The change of values is a long process which is determined by social factors and culture of society. Values of Christianity, Islam and Buddhism show different degrees of transformation. Values of Islam turn out to be the most stable in comparison to other religions.
\end{abstract}

\section{Introduction}

The aim of the article is to consider significance of religious values in the process of communication, their place and role in modern society. Besides, the authors consider it to be important to investigate main trends in the development and transformation of religious values at the modern stage of society's development.

Religious values can be defined as a stable belief that a certain model of human behavior or the ultimate goal of a person's existence is the only preferable one from a social and personal point of view, rather than a different manner of behavior or some other ultimate goal of existence [3].

The formation of religious values is a long and complex process [6]. The value motive (the driving force of value development) leads to the formation of the value itself. It starts with the level of the value ideal, being directed by a value reference point. Any religious doctrine forms its own system of values, lays the basic foundations of the faith, eventually forming a follower of a certain religious concept.

Values are closely related to the ability of a person to form various ideals. Every culture focuses its attention on an ideal that goes beyond the individual, the ideal of a community. Owing to the existing and developed system of values, a person is able to plan his or her activities changing the world and at the same time objectively evaluating himself/herself and others. On the other hand, if the system of values is rigid, devoid of dynamics and does not make amendments to a specific social context then a person will try to impose his/her values on others [2].

Values that function in a society which has strong value traditions or in a particular institution of a given society (for example, religious), which also distinguishes the presence of strong value's traditions; contribute to a faster process of a person's socialization, his/her harmonious joining a certain context of social environment.

\section{Materials and Methods (Model)}

The following methods have been used to conduct research and to fulfill the set tasks: semantic analysis, discourse-analysis, informants' survey, method of analysis of cultural meanings.

Some questions raised and studied in the article have been considered in the works of researchers conducting cultural studies (A.I. Arnoldov, A.K. Bayburin. A.A. Gorelov, P.S. Gurevich, V.N. Toporov, A.L. Kroeber, C. Kluckhohn, L.A. White), sociologists (A.I. Kravchenko, P.A. Sorokin), philosophers (A.K. Adamov, S.F. Anisimov, M.S. Kagan, A.F. Losev, G. Rickert), linguists (N.D. Arutyunova, A. Wezsbitska, E.M. Vereschagin, V.I. Karasik, V.A. Maslova), scientists conducting religious studies (V.I. Garadzha, I.A. Ilyin, A. Donnini, K.G. Dowson, V.V. Kasevicj, Y.A. Kimlev, R.L. Johnstone, R.R. Marrett).

\section{Results and Discussion}

In the most general form, the significance of values can be reduced to three points: 1) values contribute to the formation of interests, motives and goals; 2) values act as regulators and criteria for evaluating people's behavior and actions; 3) values allow you to learn the essence of a man, the meaning of his/her life [4].

M. Rokich singled out the functions of values as standards that guide everyday human activity: a) values play the role of a purpose, as they force a person to determine his/her position on specific issues and become an adherent of a particular religious ideology; b) values orient an individual in a social or religious space, forcing to evaluate and make judgments, approving or condemning one's own behavior or behavior of other

*Corresponding author new_life@mail.ru 
individuals and groups, and, therefore, constitute the basis of the content of processes of interpersonal and intergroup relations; c) values act as an instrument for an individual to adapt to a certain environment (in particular, a religious one) [7].

Any religion determines the nature of special relationship - the relationship of man with God; but at the same time it regulates the relations of people among themselves both in the religious sphere and beyond its limits. According to F. Schleiermacher: "History ... should gratefully ... reward religion as its first teacher" [5], because the highest manifestations of human spirit owe their existence to the desire of a man for the absolute, for God, for faith [1].

Religious values are a timeless phenomenon and can be presented as initial fundamental principles that can be defined as "principles", "laws", "attitudes", "commandments", etc. The peculiarity of religious values consists in their open statement - these values are transmitted in the form of parables, etc., touching upon the most relevant issues and problems of people.

The functioning of values is the influence of the latter on human activity, human behavior, on social life and on the development of culture [5].

Christian values have received the status of timeless and supranational phenomenon due to the influence of Christianity on the person and culture in general. The influence of Christian values on a person lies in the fact that Christianity: a) elevated people's morality, b) contributed to mitigating the disposition that existed earlier in society, c) directed human activity towards the creation and affirmation of goodness. The impact on the family can be explained by the fact that Christianity a) strengthened the institution of marriage, b) eradicated polygamy. The influence on society was manifested in the fact that Christianity: a) stopped revenge, b) destroyed the slave status of a person, c) made Christian qualities the qualities of every civilized person. The influence of Christianity on culture is expressed in the fact that Christianity a) revealed the essence of love, b) explained the essence of holiness, c) began to cultivate teaching and education, d) had positive impact on culture and art (stimulated typography), e) initiated "dialogue of cultures". The influence of Christianity on legality and law is that Christianity a) laid the foundation for the fact that all laws began to be based on Christian teaching about life and relationships among people, b) a number of political movements borrowed from Christians some items for their programs (for example, "freedom, equality, brotherhood"). The influence of Christianity on other religions is that Christianity softened the disposition of pagan religions.

A list of values postulated by Christian doctrine is extremely extensive. The most significant of them are: God (divine), faith, life, good (kindness), truth, love, mercy, poverty (denial of material goods), modesty, suffering, compassion, humility, forgiveness, morality.

It is interesting to trace the dynamics of development and changes in the value picture of Christianity. Analysis of modern surveys showed that the most stable and unchanging are the values associated with basic concepts such as life, truth, and good.
We conducted an interview, the results of which allowed us to present the following picture of the Christian values functioning at the present stage of society's development. In order to get a more objective picture, we attracted informants of different age groups, as well as people of varying degrees of churching. Speaking of the dyad "believers: non-believers" (churched: unchurched), we noted that the picture of values within this group is as follows. Believers (churched people) noted the presence of value significance in all considered Christian values. For people who share the foundations of Christianity, almost all the values that were established by Christian doctrine, have survived to this day in the invariable way, having retained their significance. In the group conventionally designated as "unchurched" (in which we include both non-believers (atheists) and simply "sympathizers" (who have no firm faith, hesitant), life, good, truth, compassion were included in a list of values. Currently for this group such values as God (divine), faith, mercy, poverty (disregard for material goods), modesty, suffering, humility, forgiveness, purity of morals have no significance.

Considering the distribution of value priorities in different age groups, we noted that the group "young people (youth)" included such notion as: life, kindness (kindness), truth in the list of values. All the other concepts considered in our study did not receive value markings. Middle-aged people categorized such values as God (divine), faith, life, goodness (kindness), truth, mercy, and compassion as values. By elderly people, almost all the categories considered were classified as values.

All categories of informants mentioned "life", "good (kindness)", "truth" as value marking. Thus, such Christian categories as life, kindness, and truth retain enduring value over many millennia. Probably, the awareness of the inner essence of these concepts is changing with the development of society and culture but they still relate to the number of values.

Let us focus on such a value as love. This concept was also included in the category of values by all informants, but different groups noted different semantic aspects of this value. The outlined semantic characteristics fully coincided with those components that we noted while analyzing the characteristics of the realization of the value of "love" in a religious Christian context. The components "love for another person (friend, enemy)" and "love for the Lord" turned out to be the most significant in terms of value for believers, as well as for people of the older age category; the "selflove" component showed the maximum importance for informants of a younger age, as well as for people who are unchurched (non-believers).

Recently Russian Orthodox Church published a list of "eternal values" that seem relevant to modern society. These include: 1) justice, 2) freedom, 3) solidarity, 4) conciliarism, 5) self-restraint (sacrifice), 6) patriotism, 7) the good of man, 8) human dignity. Love, faith and care for children and elderly people, united by a single foundation - "family", were singled out in a separate group. The above-mentioned values were defined as 
"secondary" in relation to traditional Christian values since their specific feature is determined both by the Holy Scripture and the features of the development and functioning of modern society.

Despite the fact that religious values are the most fundamental part of any culture and society that shares the foundations of a given religious dogma, during the society's development, significance of each of them can change. A number of religious values remain unchanged for thousands of years because they reflect universal principals for all times and for different social groups such Christian values as life, kindness, truth, love demonstrate the lasting value almost throughout the history of society. Others, while maintaining the status of "values", may (at the present stage of social development) for some time relegate to the background and remain significant for a certain social group (which is explained by the peculiarities of the development and functioning of society).

The values of modern Islam can be divided into three groups: 1) values of necessity; 2) value of convenience; 3) value of refinement (luxury). Values of necessity include: life, faith, family life, children, wealth. Values of convenience include various activities and things that are not vital but are needed in different life situations (as a rule, we are talking about material values). And, finally, values of refinement (luxury) - these are values that go beyond convenience and are designed to create additional comfort.

Among the basic values of Islam there can be identified such as faith and God, home and family, as well as freedom. These values occupy a prior position in the religious culture of modern Islam. At the same time, historically developed values (justice, knowledge) continue to be relevant in modern society. Thus, all values that were historically developed and presented in the religious concept of Islam continue to be relevant in modern culture, retaining their value significance. The order of their ranking changes a little. If in the traditional Islamic religious culture, values were arranged as follows according to their significance: faith and God, life, freedom, justice, family, knowledge, property; then in modern society, the first positions are occupied by faith and God, home and family, freedom. However, the concepts of justice and knowledge (the process of learning) still retain their value.

It can be stated that Buddhism belongs to the category of "ethical religions" because the Buddhist tradition has given rise to various postulates in the field of morality and proper behavior. At the same time, Buddhist ethics cannot be understood in isolation from the main goal of Buddhism - the final liberation from attachment to this world.

Recent studies show that at the present stage of society's development values of Buddhism have undergone some changes. Analysis of values of modern Buddhist culture has shown that at the present stage of society's development, several modified values come to the fore: cleansing the mind and developing wisdom, compassion, the law of karma and rebirth.

Thus, in modern Buddhism, as in the traditional, certain complex concepts are values, however, as in traditional Buddhism, these concepts presuppose that a person has certain moral qualities that have lasting value.

\section{Conclusion}

Despite the fact that religious values are the most fundamental part of any culture and society that shares the foundations of a given religious dogma, the significance of each of them changes in the process of the development of global communication of modern society.

Speaking about the development and change of religious values, we can note that values of Islam demonstrate the greatest stability. All the considered values of Islam continue to be relevant in modern culture. The distinctive feature of contemporary Christian values is that, in general, while preserving its value significance, each of the concepts examined retains its significance for a particular social group. There have been some changes in the value system of Buddhism. Initially there were such Buddhism values: the right views of a person, the right determination (intentions), the right speech, the right behavior (actions), the right way of life, the right efforts, the right attention, the right concentration, which are some kind of "prescriptions" to man - turned out to be "compressed" to the result to which they ultimately are called upon to lead a person: cleansing the mind and developing wisdom, compassion and respecting the law of karma and rebirth. This situation can be explained by the special nature of Buddhism, which is among the ethical philosophies and this character of the religious concept of Buddhism makes it more flexible to any social changes.

\section{References}

1. E.V. Bobyreva, O.A. Dmitrieva, M.R. Zheltukhina, M.V. Busygina, in Proceedings of the 7th International Scientific and Practical Conference Current Issues of Linguistics and Didactics: The Interdisciplinary Approach in Humanities, Advances in Social Science, Education and Humanities Research, Principle "Understanding" from Perspective of Linguistic Investigations, 97, 52-56 (2017)

2. E. Bobyreva, M. Zheltuhina, O. Dmitrieva, M. Busygina, SHS Web Conf., Role and Place of Religious Consciousness in Culture Formation, 50 (2018) $01035 . \quad$ DOI: https://doi.org/10.1051/shsconf/20185001035 20.10.18.(2018)

3. E. Akhverdiev, A. Ponomarev, SHS Web Conf., Vol. 50 (2018). - The International Scientific and Practical Conference "Current Issues of Linguistics and Didactics: The Interdisciplinary Approach in Humanities and Social Sciences" Religion as Factor in Formation of Law: Current trends, URL: https://doi.org/10.1051/shsconf/20185001024 20.10.18. (2018)

4. S.E. Krivykh, Armavir: Armavir Orthodox Social Institute, Axiology of world religions: a comparative 
typology of value structures: dis. ... Cand. Phil. Sciences, 174 (2009)

5. I.F. Pecherkina, Value as a regulator of the behavior of subjects, (1995)

6. M. Rokych, "The nature of human values" (M.: New York, 1973).

7. N.Z. Chavchavadze, Culture and values, 70 (Tbilisi: Metsniereba, 1984)
8. F. Schleiermacher, Speech about religion to the educated people who despise it, 432 (SPb.: Aletheia, 1994).

9. Ter Minasova S. in Russian Journal of Linguistics. Vestnik RUDN, Contradictions of International era of Globalization: Obstacles and Driving Forces 19 43-49 (2015). 